Ibrahim Assabane; Ouail EL Imrani; Salmane Bourekkadi; Ali Aboulhassane; Jerry Mounir

\title{
STUDY ON THE IMPACT OF SMART AND INNOVATIVE DELOCALIZATION PRACTICES ON INTERNATIONAL TRADE
}

\author{
Ibrahim Assabane \\ School of Information Sciences, Avenue Allal Al Fassi, Rabat, Morocco, \\ assabane2@gmail.com \\ Ouail EL Imrani \\ Abdelmalek Essaadi University, Avenue Khenifra, Tétouan 93000, Morocco, \\ oelimrani@uae.ac.ma (corresponding author) \\ Salmane Bourekkadi \\ Poitiers University, 15 Rue de l'Hôtel Dieu, TSA 71117, 86000 Poitiers, France, \\ salmane.bourekkadi@gmail.com \\ Ali Aboulhassane \\ Ibn Tofail University, Avenue de L'Université, Kenitra, Morocco, \\ alaboulhassane@yahoo.fr \\ Jerry Mounir \\ Ibn Tofail University, Avenue de L'Université, Kenitra, Morocco, \\ jemounir@yahoo.fr
}

Keywords: smart delocalization, international trade, optimization, supply chain engineering

Abstract: Faced with cumulative competition linked to the globalization of markets and increasingly stringent requirements in terms of performance, many companies are led to ask the question of delocalization part or all of their activities. Delocalization or Offshoring is a strategic decision that requires companies to review and reconfigure their methods of managing operations, especially those relating to the supply chain. The work objective is based on the key factors to be taken into account for the design of the supply chain in the context of offshoring in a context of demand for innovation. First, we address the problem of defining delocalization / Smart Delocalization and Supply Chain. Then, we review the literature to define the specificities of the problem of relocations and their impact on international trade, in particular the case of Morocco, and thus identify all the factors and constraints to be taken into account during the reconfiguration of the chain. supply chain in order to adapt it to the context of the practice of smart delocalization in an innovative context.

\section{Introduction}

The current economic context is characterized by increasingly volatile and unpredictable demand. As a result, the business environment has changed significantly and has become more complex and more difficult to predict than ever. Companies are facing multiple challenges, in particular shortening product life cycles, increasingly fierce competitive pressure, as well as new industrial and environmental constraints. In addition, these last decades have known a very strong technological evolution in particular in the field of information and communication technologies supporting the information system. These new information and communication technologies have enabled the emergence and development of new relationships within companies as well as between these companies. They have fostered a certain functional and technical integration necessary for the globalization of markets and the globalization of competition. To ensure their sustainability, firms are led to ask the question of a partial or total relocation of their activities.

\section{General context of smart delocalization 2.1 International supply chain}

The supply chain has become of crucial importance in business management. It represents an operational link between the various activities of the company [1], ensuring the consistency and reliability of material flows, with a view to the quality of service to customers while allowing the optimization of resources and reduction of costs [2].

\subsection{The smart delocalization}

Everyone understands intuitively that delocalization means transferring production from the national territory to other countries. However, the reality turns out to be more complex. Indeed, delocalization is often confused with other concepts (such as deindustrialization, outsourcing [3]. Smart delocalization allows the intelligent use of all tools and techniques to allow the company to minimize costs while gaining the maximum for all stakeholders. From beyond that the concept of innovation appears, then that it is a question of looking for intelligent solutions of 
Ibrahim Assabane; Ouail EL Imrani; Salmane Bourekkadi; Ali Aboulhassane; Jerry Mounir

delocalization, this implies the implementation of innovative outputs.

Table 1 and Table 2 highlights a few definitions cited in the literature.

Table 1 Summarizes the different definitions found in the literature that we consider the most relevant

\begin{tabular}{|c|l|}
\hline $\begin{array}{c}\text { Author } \\
\text { Billington, } \\
\mathbf{1 9 9 3}\end{array}$ & $\begin{array}{l}\text { The supply chain is a network of facilities } \\
\text { that provides the supply of raw materials, } \\
\text { the transformation of these raw materials } \\
\text { into components and then into finished } \\
\text { products, and the distribution of finished } \\
\text { products to the customer. }\end{array}$ \\
\hline Génin, & $\begin{array}{l}\text { A supply chain is a network of } \\
\text { organizations or functions geographically } \\
\text { dispersed across several cooperating sites, } \\
\text { to reduce costs and increase the speed of } \\
\text { processes and activities between suppliers } \\
\text { and customers. If the goal of customer } \\
\text { satisfaction is the same, the complexity } \\
\text { varies from one supply chain to another. }\end{array}$ \\
\hline $\begin{array}{c}\text { Fulconis } \\
\text { et al, 2009 }\end{array}$ & $\begin{array}{l}\text { Transversal approach planning, } \\
\text { implementing and controlling physical } \\
\text { and information flows from the point of } \\
\text { consumption to the point of origin }\end{array}$ \\
\hline
\end{tabular}

Table 2 Definitions of delocalization

\begin{tabular}{|c|c|}
\hline Author & Definition \\
\hline $\begin{array}{l}\text { Arthuis } \\
2005\end{array}$ & $\begin{array}{l}\text { Delocalization brings together all the } \\
\text { arbitrations carried out by companies } \\
\text { against the location of activities and jobs } \\
\text { in the country of origin. }\end{array}$ \\
\hline $\begin{array}{l}\text { Aubert et } \\
\text { sillard } \\
2005\end{array}$ & $\begin{array}{l}\text { It is the substitution of foreign production } \\
\text { by domestic production resulting from the } \\
\text { arbitration of a producer who gives up } \\
\text { producing in the country of origin to } \\
\text { produce or subcontract abroad. }\end{array}$ \\
\hline $\begin{array}{l}\text { Hammami } \\
2008\end{array}$ & $\begin{array}{l}\text { Delocalization is the transfer by direct } \\
\text { investment abroad of all or part of a } \\
\text { productive process, the production of } \\
\text { which is originally intended for the same } \\
\text { markets as before, in order to maximize } \\
\text { the added value of the activities of the } \\
\text { firm. }\end{array}$ \\
\hline $\begin{array}{c}\text { Kinkel et } \\
\text { Maloca } \\
2009 \\
\end{array}$ & $\begin{array}{l}\text { Delocalization of production capacity } \\
\text { means relocation of this capacity abroad. }\end{array}$ \\
\hline
\end{tabular}

Bernard et al. distinguish three types delocalization: delocalization with cessation or reduction of activity in the country of origin, i.e. the transfer to a host country of all production or a link in the production chain of goods or services with cessation of activity and / or employment in the parent company [4], delocalization with global expansion of the activity: this is the start in a country reception of a production or a link in the production chain of goods or services similar to those of the country of origin without stopping or reducing activity and / or employment and delocalization with diversification of the activity: Establishment in a host country of a production of goods or services related or not to the productions of the parent company in the country of origin [5].

The current economic situation, characterized by fierce competition, shortages in energy and raw materials, the saturation of markets, informed customers, means that companies are in search of competitive advantages allowing them to stay ahead of their local [6], national and international competitors, to ensure their sustainability [7].

The competitive advantages sought essentially revolve around two major issues cited in Table 3.

Table 3 The causes of delocalization

\begin{tabular}{|l|l|}
\hline \multicolumn{1}{|c|}{$\begin{array}{c}\text { Optimization of } \\
\text { production costs }\end{array}$} & \multicolumn{1}{|c|}{$\begin{array}{c}\text { Selling on the local } \\
\text { market }\end{array}$} \\
\hline $\begin{array}{l}\text { Benefit from a cheaper } \\
\text { workforce }\end{array}$ & $\begin{array}{l}\text { Getting closer to } \\
\text { consumer markets }\end{array}$ \\
\hline $\begin{array}{l}\text { Overcome all the } \\
\text { constraints of western } \\
\text { countries }\end{array}$ & $\begin{array}{l}\text { Overcome various } \\
\text { obstacles to the export } \\
\text { (quotas, customs taxes ...) } \\
\text { of emerging countries }\end{array}$ \\
\hline $\begin{array}{l}\text { Benefit from advantages } \\
\text { offered. Some LowCost } \\
\text { countries offer additional } \\
\text { services to companies } \\
\text { setting up. }\end{array}$ & $\begin{array}{l}\text { Free yourself from } \\
\text { exchange rate variations }\end{array}$ \\
\hline
\end{tabular}

If the negative consequences for the countries undergoing delocalization are often put forward, we forget the positive consequences on the countries which benefit from these delocalization s. This is why, a complete understanding of the problem of delocalization [8], requires to see this phenomenon from two points of view, in the countries undergoing delocalization it is necessary that delocalization allows to increase the competitiveness of companies by lowering the costs of certain intermediate consumption, losing indirect jobs and redundancies, lowering the price of consumer goods, which favours the purchasing power of households [9]. While in the host countries: The consequences are often very positive for countries benefiting from outsourcing, in particular emerging countries [10]. They allow in particular to Create new jobs, by the transfer of production centers, Allow the transfer of know-how and techniques, often necessary for relocation to succeed, gradually increase the standard of living of these countries [11].

\section{Impact of smart delocalization on international trade}

\subsection{The design of the international supply chain}

Efficient supply chain design and management enables the production and delivery of a variety of products at a 
STUDY ON THE IMPACT OF SMART AND INNOVATIVE DELOCALIZATION PRACTICES ON INTERNATIONAL TRADE

Ibrahim Assabane; Ouail EL Imrani; Salmane Bourekkadi; Ali Aboulhassane; Jerry Mounir

low cost, of good quality and in times beyond competition [12]. Sink and al. sees that the design and management of the supply chain are aimed at obtaining the best overall performance so as to obtain better performance from each of the links in the chain [13].

Martel describes in a research work the problem of designing the supply chain as strategic, multi-criteria and complex [14].

The design of the supply chain plays the role of the determining factor of the success of the relocation. However, there are a number of aspects to take into account for the design and management of the supply chain which can be strategic, tactical or operational [15].

The choice of delocalization concerns the design of the supply chain and is one of the long-term management problems of the chain, ie deciding on the installations and the links between the installations. This results in localization / allocation problems in the supply chain.

\subsection{The criteria involved in the delocalization decision}

Since the beginning of the 1980s, many Western companies have chosen to relocate their factories or their supplies to countries with low labour costs in order to reduce their costs, in a verticalization approach; other companies, attracted by the importance of potential demand in emerging high-growth countries, are outsourcing in order to produce as close as possible to local markets, in a horizontalization strategy [16].

Analysis of the literature shows the existence of two approaches: the first, financial, emphasizes the profitability of investments, while the second deals with the strategic and managerial aspects of delocalization operations [17].

The financial approach makes it possible to estimate the profitability of a delocalization operation, while the risk management approach considers that the delocalization of production is based on opportunities but also on taking risks into account to avoid failure of the project [6].

\subsection{Design models for the production line}

In this section, a literature review of mathematical models of supply chain design is proposed in order to identify trends in the literature and issues related to the design of the supply chain.

Lambiase proposes a classification of the mathematical models existing in the literature according to four axes: Strategic decisions, economic parameters, constraints and characteristics of the models [18].

According toa research work there is no literature where all the decisions involved in strategic planning and the design of the supply chain are taken into account [1922].

It is based on the design aspects of the supply chain to discuss the existing models and see if they are adapted to the delocalization problem. It therefore focuses on models that include the decision to locate production and distribution sites because it represents the basis of the problem of delocalization.

In this research work we study 10 models classified as follows: 1- [Arntzen \& al. 1995] 2- [Huchzermeier \& Cohen 1996] 3- [Jayaraman \& Pirkul 2001] 4- [Vidal \& Goetschalckx 2001] 5- [Verter \& Dasci 2002] 6- [Yan \& al. 2003] 7- [Fandel \& Stammen 2004] 8- [Melo \& al. 2005] 9- [Vila et al. 2006] 10- [Hammami 2008], [3,13,15,23-29].

The taxonomy in the literature of the models cited above is based on three axes: decisions, costs, constraints.

\subsubsection{Decision variables}

The Decisions cited in the following table are the most relevant in the context of offshoring. According to models that integrate all of these aspects are rare (Table 4).

Table 4 The Classification of models integrating decision variables

\begin{tabular}{|c|c|c|c|c|c|c|c|c|c|c|}
\hline & 1 & 2 & 3 & 4 & 5 & 6 & 7 & 8 & 9 & 10 \\
\hline Location of sites & $\sqrt{ }$ & $\sqrt{ }$ & & $\sqrt{ }$ & $\sqrt{ }$ & $\sqrt{ }$ & $\sqrt{ }$ & $\sqrt{ }$ & $\sqrt{ }$ & $\sqrt{ }$ \\
\hline $\begin{array}{c}\text { Choice of } \\
\text { technologies }\end{array}$ & & & & $\sqrt{ }$ & & & & $\sqrt{ }$ & & \\
\hline $\begin{array}{l}\text { Relocation of } \\
\text { capacities }\end{array}$ & & & & & & & & & & \\
\hline $\begin{array}{l}\text { Choice of } \\
\text { suppliers }\end{array}$ & & $\sqrt{ }$ & $\sqrt{ }$ & & $\sqrt{ }$ & $\sqrt{ }$ & & & $\sqrt{ }$ & $\sqrt{ }$ \\
\hline $\begin{array}{c}\text { Intermediate } \\
\text { products }\end{array}$ & & $\sqrt{ }$ & & $\sqrt{ }$ & & & $\sqrt{ }$ & & & $\sqrt{ }$ \\
\hline Transfer price & & & $\sqrt{ }$ & & & & $\sqrt{ }$ & & & \\
\hline $\begin{array}{l}\text { Transport cost } \\
\text { allocation }\end{array}$ & & $\sqrt{ }$ & & & & & $\sqrt{ }$ & & & \\
\hline $\begin{array}{c}\text { General } \\
\text { expenses } \\
\text { allowance }\end{array}$ & & & $\sqrt{ }$ & & & & & & & \\
\hline
\end{tabular}

\subsubsection{Cost factors}

The costs are always included in the supply chain design models; a research work identified the costs relevant to the problem of delocalization. Apart from model 13, no model takes into account the cost of labour (Table 5), so the costs of stocks in transit are rarely taken into account.

Table 5 The Classification of models according to the consideration of cost factors

\begin{tabular}{|c|c|c|c|c|c|c|c|c|c|c|}
\hline & $\mathbf{1}$ & $\mathbf{2}$ & $\mathbf{3}$ & $\mathbf{4}$ & $\mathbf{5}$ & $\mathbf{6}$ & $\mathbf{7}$ & $\mathbf{8}$ & $\mathbf{9}$ & $\mathbf{1 0}$ \\
\hline Site closure & & & & & & & & & & \\
\hline $\begin{array}{c}\text { Fixed supplier } \\
\text { cost }\end{array}$ & & $\sqrt{ }$ & $\sqrt{ }$ & & & & & & $\sqrt{ }$ & $\sqrt{ }$ \\
\hline Labour cost & & & & & & & & & & \\
\hline $\begin{array}{c}\text { Fixed cost } \\
\text { technologies }\end{array}$ & & & & $\sqrt{ }$ & & & & & & \\
\hline Capacity cost & & & & & & & & $\sqrt{ }$ & & \\
\hline Storage cost & & & & $\sqrt{ }$ & & & $\sqrt{ }$ & & & $\sqrt{ }$ \\
\hline
\end{tabular}


Ibrahim Assabane; Ouail EL Imrani; Salmane Bourekkadi; Ali Aboulhassane; Jerry Mounir

\begin{tabular}{|c|c|c|c|c|c|c|c|c|c|c|}
\hline $\begin{array}{c}\text { Cost of stock in } \\
\text { transit }\end{array}$ & & & & & & & & & \\
\hline Site closure & & & & & & & & & & \\
\hline $\begin{array}{c}\text { Fixed supplier } \\
\text { cost }\end{array}$ & & $\sqrt{ }$ & $\sqrt{ }$ & & & & & & $\sqrt{ }$ & $\sqrt{ }$ \\
\hline
\end{tabular}

\subsubsection{Constraints}

This table (Table 6) represents the constraints imposed by the delocalized environment; we note that the models which take into account the technological constraints which are important in the case of delocalization - are very rare in the literature. The same applies to the constraints of local content.

Table 6 Models that take into account constraints

\begin{tabular}{|c|c|c|c|c|c|c|c|c|c|c|}
\hline & $\mathbf{1}$ & $\mathbf{2}$ & $\mathbf{3}$ & $\mathbf{4}$ & $\mathbf{5}$ & $\mathbf{6}$ & $\mathbf{7}$ & $\mathbf{8}$ & $\mathbf{9}$ & $\mathbf{1 0}$ \\
\hline $\begin{array}{c}\text { Technological } \\
\text { constraints }\end{array}$ & & & & & & & & & & \\
\hline $\begin{array}{c}\text { Supplier } \\
\text { capacity }\end{array}$ & & $\sqrt{ }$ & $\sqrt{ }$ & & $\sqrt{ }$ & $\sqrt{ }$ & $\sqrt{ }$ & & $\sqrt{ }$ & $\sqrt{ }$ \\
\hline Local content & & & $\sqrt{ }$ & $\sqrt{ }$ & & & & & & \\
\hline
\end{tabular}

The results of this classification allowed us to note that the majority of the models proposed seek to maximize the objective function, so we noticed that there is a rarity of models which take into account the cost of labour (Table 7), the constraints technology and delivery time:

Table 7 Results of model analysis

\begin{tabular}{|c|c|c|}
\hline Decisions & $\begin{array}{l}\text { Transfer price } \\
\text { Delocalization of } \\
\text { capacities } \\
\text { Allocation of } \\
\text { overheads }\end{array}$ & $\begin{array}{l}2 \text { models } \\
3 \text { models } \\
2 \text { models }\end{array}$ \\
\hline Costs & $\begin{array}{c}\text { Labour cost } \\
\text { Fixed cost technology } \\
\text { Stock in transit cost }\end{array}$ & $\begin{array}{l}1 \text { model } \\
3 \text { models } \\
3 \text { models } \\
\end{array}$ \\
\hline Constraints & $\begin{array}{l}\text { Technological } \\
\text { constraints } \\
\text { Local content } \\
\end{array}$ & $\begin{array}{l}1 \text { model } \\
2 \text { models }\end{array}$ \\
\hline
\end{tabular}

\section{Morocco an excellent host country for delocalization and offshoring}

Morocco has entered the internationally recognized outsourcing destinations, particularly in the Frenchspeaking world. Thus, the Morocco destination is systematically considered in the majority of Delocalization decisions and reference players have trusted Morocco [17].

Being aware of the challenges of offshoring and of the opportunities generated by this wave of globalization, Morocco has taken incentive measures to attract foreign direct investment (FDI), which is an engine of growth for the national economy.

The new investment attraction strategy adopted by Morocco as part of the "Industrial Emergence Plan" promises to be a kind of redefinition of Moroccan industrial policy. This redeployment is intended to be strategic in view of the competitiveness challenges that the country is faced with following the alarming findings of the country's economic situation, which is strongly linked to industrial structures [20].

\subsection{SWOT analysis of the industrial sector in Morocco}

We highlight in Table 8 the factors that make Morocco an attractive platform for the relocation of industrial firms as well as the weaknesses and threats that can slow down this relocation movement.

Table 8 SWOT analysis of the industrial sector in Morocco

\begin{tabular}{|c|c|}
\hline Strengths & Weak points \\
\hline $\begin{array}{l}\text {-Geographic proximity to } \\
\text { Europe and timetable } \\
\text {-Modernization } \\
\text { production tools } \\
\text {-Flexibility to adapt to } \\
\text { new markets } \\
\text {-Standardization and } \\
\text { quality approach } \\
\text {-Quality and cost of } \\
\text { labour }\end{array}$ & $\begin{array}{l}\text {-Low importance to } \\
\text { research and development } \\
\text {-Difficulties in correctly } \\
\text { using production tools } \\
\text {-Technological delay } \\
\text {-Delay in the } \\
\text { transformation } \\
\text { globalization }\end{array}$ \\
\hline Opportunities & Threat \\
\hline $\begin{array}{l}\text {-Willingness } \\
\text { delocalize European } \\
\text { equipment manufacturers } \\
\text { (Cost reduction) } \\
\text {-Very smart customs } \\
\text { dismantling } \\
\text {-Creation of an } \\
\text { automotive technical } \\
\text { center } \\
\text {-Upward trend in the } \\
\text { national automobile } \\
\text { market }\end{array}$ & $\begin{array}{l}\text {-Inability to control unfair } \\
\text { competition } \\
\text {-Slow responsiveness to the } \\
\text { demands of globalization } \\
\text { and the free trade area }\end{array}$ \\
\hline
\end{tabular}

\subsection{Discussion}

Our research work goes in the direction of strengthening the position of Morocco among the target countries of the relocation of large international companies.

Our contribution will take on a technical and engineering aspect, by proposing a mathematical model for the design and optimization of the supply chain in a delocalized environment. This model will be a decisionmaking tool for multinationals looking to relocate their activities to Morocco, and even for Moroccan companies that are studying investment opportunities outside the national territory.

After having identified the characteristics of the phenomenon of delocalization and based on how these characteristics impact the design of the supply chain, we 
Ibrahim Assabane; Ouail EL Imrani; Salmane Bourekkadi; Ali Aboulhassane; Jerry Mounir

are led to examine the models of the supply chain existing in the literature and see if these models are well suited to context of delocalization.

With this in mind, we have reviewed the analytical approaches to supply chain design as well as the classification of existing models according to well-defined axes of analysis. This classification allowed us to identify the model that best takes into account aspects of delocalization.

In perspective, we plan to verify and improve this model by adding relevant factors to take into consideration when designing the supply chain in the context of delocalization.

\section{Conclusions}

One of the major challenges for companies is to contribute to growth by helping to re-establish the relocation of some of the company's activities. The Challenge consists in creating conditions that promote long-term competitiveness capable of bringing in innovative solutions. Delocalization leads to an increasingly complex industrial organization. It is therefore important to consider the company beyond its usual structure, taking overall account of its suppliers and customers. Delocalization or smart Delocalization innovations are multiplying and competition is becoming increasingly fierce.

The problem relates to the modelling of the logistics chain in the context of delocalization for optimized management.

This study allowed us to perceive the importance of offshoring today and its issues that must be studied in depth, we established a state of the art to understand the particularities of the phenomenon of delocalization and to define the parameters and factors to be taken into consideration in the development of an economic model of the international supply chain in the context of smart delocalization which will improve international trade better.

\section{References}

[1] LAYTI, M.B.M., EL IMRANI, O., MEDOURI, A., RAJAA, M.: Logistics Information Systems and Traceability of Pharmaceutical Products in Public Hospitals in Morocco: What Solutions to Improve the Supply Chain, Advanced Intelligent Systems for Sustainable Development (AI2SD'2019), AI2SD 2019, Advances in Intelligent Systems and Computing, Vol. 1104, Springer, Cham, 2019.

[2] HAMMAMI, R., FREIN, Y.: Redesign of global supply chains with integration of transfer pricing: Mathematical modeling and managerial insights, International Journal of Production Economics, Vol. 158, No. December, pp. 267-277, 2014.

[3] HAMMAMI, R., FREIN, Y., HADJ-ALOUANE, A.B.: Supply chain design in the delocalization context:
Relevant features and new modeling tendencies, International Journal of Production Economics, Vol. 113, No. 2, pp. 641-656, 2008.

[4] RUDOLF, O.L., NIKOLAI, K., RAHEL, K.H.: Procurement of logistics services and sustainable development in Europe: Fields of activity and empirical results, Journal of Purchasing and Supply Management, Vol. 19, No. 3, pp, 122-133, 2013.

[5] LAMBIASE, A., MASTROCINQUE, E., SALVATORE, M., LAMBIASE, A.: Strategic Planning and Design of Supply Chains: a Literature Review, International Journal of Engineering Business Management, Vol. 5, No. 49, pp. 1-11, 2013. doi: $10.5772 / 56858$

[6] CHIBISOV, O.V., CHIBISOVA, E.I., KAZANTSEVA, S.Y.: Improvement of corporate operations in inventory management, International Journal of Applied Business and Economic Research, Vol. 15, No. 8, pp. 29-41, 2017.

[7] PIPAME: Relocalisations des activités industrielles en France: revue de la littérature, PIPAME, SEMAPHORES, Ivry-sur-Seine, 2013. (Original in French)

[8] BOUREKKADI，S., EL IMRANI，O., KANDILI, M.E.L., SLIMANI, K., KHOULJI, S., BABOUNIA, A.: Intelligent solution based on information technologies - The correct value of the business in economic organization is intangible asset, Proceedings of the $33^{\text {rd }}$ International Business Information Management Association Conference, IBIMA 2019: Education Excellence and Innovation Management through Vision 2020, pp 6310-6317, 2020.

[9] OGBO, A.I., VICTORIA, O.I., UKPERE, W.I.: The impact of effective inventory control management on organizational performance: A study of 7up bottling company Nile Mile Enugu, Nigeria, Mediterranean Journal of Social Sciences, Vol. 5, No. 10, pp. 109-118, 2014.

[10] KINKEL, S., MALOCA, S.: Localisations industrielles: les entreprises redécouvrent les vertus du made in Germany, Regards sur l'économie allemande, Vol. 95, pp. 5-14, 2010. doi:10.4000/rea.4017 (Original in French)

[11] COSTA, D., MARTINS, M., MARTINS, S., TEIXEIRA, E., BASTOS, A., CUNHA, A.R., VARELA, L., MACHADO, J.: Performance evaluation of different mechanisms of production activity control in the context of Industry 4.0, In: Gheorghe G. (eds) Proceedings of the International Conference of Mechatronics and CyberMixMechatronics - 2019, ICOMECYME 2019, Lecture Notes in Networks and Systems, Vol. 85, pp. 82-103, 2020.

[12] LEMAIRE, J-P.: Pays émergents: les investisseurs au pied du mur, L'Expansion Management Review, Vol. 137, No. June, pp. 36-45, 2010. (Original in French) 
Ibrahim Assabane; Ouail EL Imrani; Salmane Bourekkadi; Ali Aboulhassane; Jerry Mounir

[13] JAYARAMAN, V., PIRKUL, H.: Planning and Coordination of Production and Distribution Facilities for Multiple Commodities, European Journal of Operational Research, Vol. 133, No. 2, pp. 394-408, 2001. doi:10.1016/S0377-2217(00)00033-3

[14] CHACKELSON, C., ERRASTI, A., CIPRÉS, D., LAHOZ, F.: Evaluating Order Picking Performance Trade-offs by Configuring Main Operating Strategies in a Retail Distributor: A Design of Experiments approach, International Journal of Production Research, Vol. 51, No. 20, pp. 6097-6109, 2013. doi:10.1080/00207543.2013.796421

[15] VERTER, V., DASCI, A.: The Plant Location and Flexible Technology Acquisition Problem, European Journal of Operational Research, Vol. 136, No. 2, pp. 366-382, 2002. doi:10.1016/S0377-2217(01)00023-6

[16] SINK, H.L., LANGLEY, Jr. C.J.: A Managerial Framework for the Acquisition of Third-Party Logistics Services, Journal of Business Logistics, Vol. 18, No. 2, pp. 163-189, 1997.

[17] VAN HOEK, R.: The Purchasing and Control of Supplementary Third Party Logistics Services, The Journal of Supply Chain Management, Vol. 36, No. 3, pp. 14-26, 2000.

[18] DARKOW, I.-L., WEIDMANN, M., LORENTZ, H.: Adaptation of Foreign Logistics Service Providers' Resources and Capabilities to a New Institutional Environment, Journal of Supply Chain Management, Vol 51, No. 1, pp. 27-51, 2015.

[19] BEN KADDOUR, N., RAJAA, M., MEDOURI, A.: The practices of logistics service providers in Morocco: the paradox of collaboration/coordination, Acta logistica, Vol. 7, No. 3, pp. 167-174, 2020. doi:10.22306/al.v7i3.170

[20] BACHÁR, M., MAKYŠOVÁ, H.: Evaluation of the impact of intelligent logistics elements on the efficiency of functioning internal logistics processes, Acta Tecnología, Vol. 5, No. 3, pp. 55-58, 2019. doi:10.22306/atec.v5i2.50

[21] HRUŠECKÁ, D., PIVNIČKA, M., BORGES L.R.: Logistics management as a system constraint, Polish Journal of Management Studies, Vol. 15, No. 1, pp. 76-87, 2017.

[22] EL IMRANI, O.: Study to Reduce the Costs of International Trade Operations Through Container
Traffic in a Smart Port, In: Ben Ahmed M., Rakıp Karaș İ., Santos D., Sergeyeva O., Boudhir A.A. (eds) Innovations in Smart Cities Applications Volume 4. SCA 2020. Lecture Notes in Networks and Systems, Vol. 183, Springer, Cham, 2021. doi:10.1007/978-3030-66840-2_36

[23] ARNTZEN, B.C., BROWN, G.G., HARRISON, T.P., TRAFLON, L.L.: Global supply chain management at digital equipment corporation, Interfaces, Vol. 25, No. 1, pp. 69-93, 1995.

[24] HUCHZERMEIER, A., COHEN MORRIS, A.: Valuing Operational Flexibility Under Exchange Rate Risk, Operations Research, Vol. 44, No. 1, pp. 100-113, 1996.

[25] VIDAL, C.J., GOETSCHALCKX, M.: A Global SupplyChain Model with Transfer Pricing and Transportation Cost Allocation, European Journal of Operational Research, Vol. 129, No. 1, pp. 134-158, 2001.

[26] YAN, H., YU, Z., CHENG, T.C.E.: A Strategic Model for Supply Chain Design with Logical Constraints: Formulation and Solution, Computers \& Operations Research, Vol. 30, No. 14, pp. 21352155, 2003.

[27] FANDEL, G., STAMMEN, M.: A General Model for Extended Strategic Supply Chain Management with Emphasis on Product Life Cycles Including Development and Recycling, International Journal of Production Economics, Vol. 89, No. 3, pp. 293-308, 2004.

[28] MELO, M.T., NICKEL, S., SALDANHA DA GAMA, F.: Dynamic Multi-commodity Capacitated Facility Location: a Mathematical Modeling Framework for Strategic Supply Chain Planning, Computers \& Operations Research, Vol. 33, No. 1, pp. 181-208, 2006.

[29] VILA, D., MARTEL, A., BEAUREGARD, R.: Designing Logistics Networks in Divergent Process Industries: a methodology and its Application to the Lumber Industry, International Journal of Production Economics, Vol. 102, No. 2, pp. 358-378, 2006.

\section{Review process}

Single-blind peer review process. 